\title{
Mandela must look to the north
}

The burial of apartheid last week in South Africa (the practice ended some years ago) is a landmark in history, as Mr Nelson Mandela has been saying, but what some call the struggle is just beginning.

Politicians whose reputation is enhanced by their engagement in a contentious election are few and far between, but Mr Nelson Mandela is one. His demeanour during the past few weeks has been as correct as in the five years since his release from jail. That he should be able to tell the Guardian newspaper, on the eve of his appointment as president of South Africa, that he wishes to "let bygones be bygones" is itself a monumental declaration. Not many who have suffered a quarter of a century of unjust imprisonment would readily rise to that. But a period of reconciliation is precisely what South Africa needs.

What are the chances of that happening? Imponderables are evenly balanced on either side. South Africa's strength is that it is the richest country in southern Africa, and populous as well. Its weakness is that extremists of all stripes are discontented with the way the elections have turned out, while Mandela's own supporters have good cause to be impatient for an improvement of their lot. One immediate task for the new government will be to ensure somehow that the satisfaction of these demands can be contained within the available resources. Another, and more important, is to negotiate and agree a constitution that will serve for the long haul (and which must be in effect five years from now). What with the need to keep the civil peace as well, even the lion Mandela will be asking whether that is not enough to be going on with.

But there is yet more to be done. South Africa is not merely the best endowed country in Africa south of the Equator, it is also the one best placed to help rescue the remainder of the continent from what at present appears to be a nasty future. Much can be done by example, which is why the permanent constitution of the republic could have beneficial consequences far outside its borders; at least one of the causes of the slough into which Africa as a whole is falling is the pattern of inefficient, intolerant and often corrupt government that appears to be endemic. If Mandela can pacify Kwa-Zulu interests, perhaps Nigeria (much further north) need not be tearing itself apart.

There is also technical work to do. For decades, research organizations in the republic have been saying that they could help to make the rest of Africa prosperous if only they were given the opportunity. In fields as different as agriculture, public health, mining technology and construction, government agencies in the republic have much in the way of advice to offer. Hitherto, the slur of apartheid has meant that their advice, let alone involvement, in development outside the republic has been scorned. But last week's election should finally have put an end to that state of affairs, providing southern Africa as a whole with a source of nowindigenous expertise it often lacks. It would be a great misfortune for Africa in general if this opportunity were overlooked in the hectic months ahead.

\section{British research hiatus}

\section{An over-glossy statement of what the future holds leaves many important questions without answers.}

TYPOGRAPHICALly, the British government has done the scientific community of which it is the chief supporter a great honour by the lavishness of Forward Look 1994, the first of what is meant to be an annual series of publications charting the evolution of a new strategy for research. For one thing, the text appears to have been set in 9-point type on 15 points of lead, which means that white space would account for a large part of the typeset area on every page even if every character were a capital letter. The document is made even easier on the eye by the 7 -cm margin on the outside of the first 50 pages of the text and generous space between paragraphs, and by the elegant copper-simulating colour used for headings in the text and for the interleaving pages that separate chapters from each other. Those who consider the price ( $£ 30.00$ for two volumes, from HMSO) exorbitant for what is meant to be a working document will at least have a fine example of contemporary typographic design.

Sadly, the text does not live up to its appearance, either in literacy or in content. The British Civil Service, which some years ago gave the world the new English noun spend (as in "the annual spend will be...") has taken this opportunity to launch the novel noun build, which appears to signify the amount of building (physical or metaphorical) accomplished at some defined instant, and secondee, which can be taken from the context (the DTI is "increasing the number of industrial secondees within its Innovation Unit") to mean a person who has been temporarily transferred from industry to the public service. There is also a new gloss on the meaning of the noun essay; the documents include a series of writings so labelled, but misleadingly; they do not have the shape of essays (which advance a proposition and then set out to sustain it by literate argument) and which, by being anonymous, cannot be assigned intellectual weight (but the 